\title{
Meningkatkan Benefits Melalui Kepuasan Pengguna berdasarkan Kualitas Sistem Informasi
}

\author{
Muhammad Haris Fadhillah \\ Program Studi S1 Manajemen, Institut Manajemen Koperasi Indonesia \\ mharisfadhillah@ikopin.ac.id
}

\begin{abstract}
Abstrak
Tujuan dari penelitian ini adalah untuk mengetahui pengaruh kualitas sistem informasi akademik terhadap benefits melalui kepuasan pengguna sistem informasi akademik di Institut Manajemen Koperasi Indonesia. Metode penelitian yang digunakan adalah metode kuantitatif dengan pendekatan deskriptif dan verifikatif. Sampel pada penelitian ini adalah 184 mahasiswa pengguna sistem informasi akademik. Alat ukur yang digunakan adalah angket dengan jumlah item pernyataan sebanyak 21 item. Teknik analisis data menggunakan analisis jalur dengan bantuan program IBM SPSS 22.0. Berdasarkan hasil penelitian yang dilakukan, (1) kepuasan pengguna dipengaruhi oleh kualitas sistem informasi akademik, (2) benefits dipengaruhi oleh kepuasan pengguna, dan (3) benefits dipengaruhi oleh kualitas sistem informasi akademik melalui kepuasan pengguna.
\end{abstract}

Kata Kunci: Benefits, Kualitas Sistem Informasi Akademik

\begin{abstract}
The purpose of this research is to determine the influence of academic information system to benefits through user satisfaction of academic information system in Institut Manajemen Koperasi Indonesia. The research method used is a quantitative method with descriptive approach and verification approach. The sample of this research is 184 students who used academic information system. The measuring instrument used in this research is questionaire with 21 statement items. Data analysis techique using path analysis using software IBM SPS 22.0. Based on the results, (1) user satisfaction is influenced by quality of academic information system, (2) benefits is influenced by user satisfaction, and (3) benefits is influenced by quality of academic information system through user satisfaction.
\end{abstract}

\section{Keywords: Benefits, Quality of Academic Information System}

\section{PENDAHULUAN}

Sistem informasi semakin berkembang seiring dengan peningkatan kebutuhan akan informasi yang disampaikan. Hal tersebut direspon oleh beberapa sektor, salah satunya dari sektor pendidikan yaitu perguruan tinggi melalui sistem informasi akademik (SIA) yang berfungsi untuk mengelola data dosen, mahasiswa, dan lulusannya. SIA juga berfungsi untuk melaksanakan pelayanan akademik secara daring (online) seperti perwalian, pencetakan kartu hasil studi (KHS), pencetakan transkrip, jadwal kuliah, dan jadwal ujian.

Secara umum keberhasilan SIA dapat diukur dari manfaat (benefits) yang dirasakan oleh penggunanya.
Benefits merupakan manfaat-manfaat yang dirasakan oleh pengguna setelah menggunakan sistem informasi baik positif maupun negatif. Penelitian dari Ojo (2017) menunjukkan bahwa benefits berperan penting dalam penerapan sistem informasi, artinya benefits dapat menjadi salah satu tolok ukur evaluasi untuk perbaikan sistem informasi.

Penelitian mengenai benefits pada SIA telah dilakukan oleh Kerta dan Suryawan (2013) di Bina Nusantara University. Pada penelitian tersebut benefits dapat diukur melalui kualitas sistem informasi akademik sebagai variabel bebas, serta penggunaan sistem dan kepuasan pengguna sebagai variabel intervening. Dengan menggunakan model 
kesuksesan sistem informasi yang diusulkan oleh DeLone dan McLean (2003), penelitian tersebut membagi kualitas sistem informasi menjadi tiga bagian yaitu kualitas sistem, kualitas informasi, dan kualitas layanan.

Institut Manajemen Koperasi Indonesia (Ikopin) memiliki sistem informasi yang dinamakan dengan SAKTI yang merupakan singkatan dari Sistem Informasi Akademik Terintegrasi yang telah diterapkan pada tahun 2011 semester ganjil hingga saat ini. Pengguna SAKTI yaitu mahasiswa dan tenaga kependidikan. Robo et al. (2018) dalam penelitiannya membagi benefits pada SIA menjadi empat dimensi yaitu efektivitas efisiensi, fasilitas informasi akademik, dan kegunaan. Salah satu manfaat yang dirasakan oleh pengguna SAKTI yaitu kegunaan SIA yang akan disajikan dalam tabel berikut.

\section{Tabel 1. Kegunaan Layanan Sistem Informasi Akademik di Ikopin}

\begin{tabular}{|c|c|c|c|c|c|c|}
\hline \multirow{2}{*}{ No } & \multirow{2}{*}{ Layanan Akses } & \multirow{2}{*}{ Mahasiswa } & \multicolumn{4}{|c|}{ Unit Layanan Tenaga Kependidikan } \\
\hline & & & Akademik & Kemahasiswaan & $\begin{array}{l}\text { Program } \\
\text { Studi }\end{array}$ & IT \\
\hline 1 & $\begin{array}{l}\text { Penawaran Mata Kuliah } \\
\text { (Perwalian) }\end{array}$ & $\sqrt{ }$ & $\sqrt{ }$ & - & $\sqrt{ }$ & - \\
\hline 2 & Registrasi Mahasiswa & - & - & $\sqrt{ }$ & - & - \\
\hline 3 & $\begin{array}{l}\text { Aktivasi Akun } \\
\text { mahasiswa }\end{array}$ & - & - & - & - & $\sqrt{ }$ \\
\hline 4 & Cetak KRS & $\sqrt{ }$ & - & - & $\sqrt{ }$ & - \\
\hline 5 & Cetak KHS & $\sqrt{ }$ & - & - & $\sqrt{ }$ & - \\
\hline 6 & $\begin{array}{l}\text { Cetak Transkrip } \\
\text { Sementara }\end{array}$ & $\sqrt{ }$ & - & - & $\sqrt{ }$ & - \\
\hline 7 & Input Nilai Mata Kuliah & - & - & - & $\sqrt{ }$ & - \\
\hline 8 & Cetak Kartu Ujian & $\sqrt{ }$ & - & - & $\sqrt{ }$ & - \\
\hline 9 & Jadwal Kuliah & $\sqrt{ }$ & - & - & $\sqrt{ }$ & - \\
\hline 10 & Update Data Dosen & - & $\sqrt{ }$ & - & - & - \\
\hline 11 & Update Kurikulum & - & $\sqrt{ }$ & - & - & - \\
\hline 12 & Update Data Mahasiswa & - & - & $\sqrt{ }$ & - & - \\
\hline
\end{tabular}

(Sumber: Data diolah dari Bagian IT, 2020)

Manfaat lain dari SAKTI yang dirasakan oleh pengguna khususnya mahasiswa adalah efisiensi dalam proses akademik, yaitu berubahnya sistem pengambilan kartu ujian yang semula harus diambil langsung ke sekretariat program studi menjadi otomasi pada SAKTI yang dapat diakses baik melalui komputer maupun smartphone.

Dalam penerapannya, masih terdapat opini dan kritik oleh mahasiswa sebagai pengguna, diantaranya :

a. Proses loading pada SAKTI belum optimal, menurut pengelola hal ini disebabkan karena server yang dikelola belum cukup optimal dalam menampung data yang banyak terdiri dari data mahasiswa, kemahasiswaan, dan akademik;

b. Luaran (output) terdapat perbedaan antara data pada KHS dengan transkrip;

c. Kadang-kadang terjadi redundansi data mata kuliah secara otomatios oleh sistem, hal ini bisa merugikan mahasiswa karena akan mengurangis sks yang dapat ditempuh; dan

d. Saat pengguna melakukan perbaiakn data yang telah dimasukkan, pengguna harus mengisi data dari awal.

Berbagai upaya telah dilakukan oleh Ikopin untuk memperbaiki SAKTI diantaranya dengan menambah bandwidth jaringan komputer untuk mempercepat 
proses loading dan merekayasa berbagai koding dalam sistem untuk memperbaiki poin (b) sampai (d). Namun masih terdapat kendala dalam penerapannya, dan hingga kini masih dalam perbaikan.

Berdasarkan fenomena yang ada, terdapat tiga hal penting yang berkaitan dengan benefits serta kepuasan pengguna SAKTI yaitu yang berkaitan dengan kualitas sistem yang tergambar pada poin (a), dan kualitas informasi yang tergambar pada poin (b), (c), dan (d). Fenomen tersebut, juga berkaitan dengan kualitas layanan bagian IT. Kualitas layanan SIA merupakan respon dari pengelola untuk memperbaiki sistem dan informasi pada sistem informasi akademik.

Hasil studi yang telah dilakukan oleh Utami dan Samopa (2013), Fathoni et al. (2017), dan Robo et al. (2018) menghasilkan temuan bahwa kualitas ssitem informasi akademik yang terdiri dari kualitas sistem, kualitas informasi, dan kualitas layanan memiliki pengaruh terhadap kepuasan pengguna, dan kepuasan pengguna memberikan dampak positif terhadap benefits.

Berkaitan dengan fenomena benefits yang dirasakan oleh mahasiswa Ikopin diduga dipengaruhi oleh kepuasan pengguna SIA, dan kepuasan pengguna SIA diduga dipengaruhi oleh kualtias SIA. Dugaan terhadap fenomena tersebut yang menarik untuk diteliti, sehingga perlu dilakukan penelitian dengan judul Pengaruh Kualitas Sistem Informasi Akademik terhadap Benefits melalui Kepuasan Pengguna.

\section{TINJAUAN PUSTAKA}

\section{Kualitas Sistem Informasi Akademik}

Sistem Informasi Akademik (SIA) merupakan sekumpulan data akademik yang berupada data dosen, data mahasiswa, transkrip, informasi hasil studi, informasi studi yang sedang/telah ditempuh, jadwal ujian, dan lainnya. SIA yang baik adalah SIA yang mampu memenuhi kebutuhan pengguna, pada khususnya mahasiswa. Kualitas sistem informasi dapat diukur melalui kualitas sistem, kualitas informasi, dan kualitas layanan (DeLone dan McLean, 2003).

\section{Kualitas Sistem}

Kualitas sistem biasanya berfokus pada karakteristik kinerja sistem. Kualitas sistem merupakan ciri karakteristik kualitas yang diinginkan dari sistem informasi itu sendiri dan kualitas informasi yang diinginkan informasi karakteristik produk. Hal ini sesuai dengan pendapat DeLone dan McLean (dalam Saputro et al., 2015) yang menyatakan bahwa kualitas sistem adalah performa dari sistem yang merujuk pada seberapa baik kemampuan perangkat keras (hardware), perangkat lunak (software), kebijakan, prosedur dari sistem informasi dapat menyediakan kebutuhan pengguna. Radityo dan Zulaikha (2007) menjelaskan dengan menganut definisi bahwa kualitas sistem berarti kualitas dari kombinasi hardware dan software dalam sistem informasi, maka dapat disimpulkan bahwa semakin baik kualitas sistem dan kualitas output ssitem yang diberikan, akan menyebabkan pengguna tidak merasa enggan untuk melakukan pemakaian kembali (reuse), dengan demikian intensitas pemakaian sistem akan meningkat. Kualtas sistem dalam sistem informasi akademik menyangkut keterkaitan fitur dalam sistem termasuk performa sistem dan user interface.

Pada penelitian ini menggunakan empat dimensi yang diadopsi dari Livari (2005) yaitu fleksibilitas sistem (flexibility), integrasi sistem (integration), waktu respon (response time), dan kenyamanan akses (convenience of access).

\section{Kualitas Informasi}

Kualitas informasi digunakan untuk mengukur kualitas luaran (output) dari sistem informasi, yaitu kualitas yang dihasilkan oleh sistem informasi, terutama dalam bentuk laporan-laporan seperti kartu hasil studi dan transkrip (DeLone dan McLean, 1992). Kualitas informasi yang baik adalah informasi yang berkualtias tinggi, yaitu produk informasi yang karakteristik, atribut, atau kualitasnya membuat informasi tersebut menjadi lebih berharga bagi pengguna. O;Brien dan Marakas (2014) berpendapat bahwa informasi memiliki empat dimensi yaitu dimensi waktu, currency / up to date, frekuensi, dan periode waktu.

Untuk mengukur kualitas sistem informasi akademik dalam penelitian ini, digunakan empat indikator yang diadopsi dari Livari (2005) yaitu kelengkapan (completeness), ketepatan (accuracy), kekinian (currency), dan format keluaran (format of output). 


\section{Kualitas Layanan}

Kualitas layanan merupakan kualitas dukungan yang didapatkan oleh pengguna dari pengembang sistem informasi. DeLone dan McLean (2003) berpendapat hasil yang diberikan sistem informasi tidak hanya berupa produk informasi saja tetapi juga pelayanan, maka pengukuran keefektifan sistem informasi tidak hanya terbatas pada kualitas informasinya tetapi kualitas layanan. Saputro et al. (2015) menyebutkan kualitas layanan merupakan sebuah perbandingan dari harapan pengguna dengan persepsi dari layanan nyata yang diterima oleh pengguna.

Untuk mengukur kualitas layanan sistem informasi akademik dalam penelitian ini, digunakan tiga dimensi yang diadopsi dari DeLone dan McLean (2003) yaitu jaminan (assurance), empati (empathy), dan kesegeraan (responsiveness).

\section{Kepuasan Pengguna}

Kepuasan pengguna sistem informasi merupakan respon dan umpan balik yang dimunculkan pengguna setelah menggunakan sistem informasi. Sikap pengguna merupakan kriteria subjektif mengenai seberapa puas pengguna terhadap sistem informasi yang telah diterapkan dan digunakan. Persepsi pengguna sistem tentang pentingnya sistem menunjukkan tingkat ketergantungan dari pengguna terhadap sistem (Sudarmadi, 2010). Kepuasan pengguna dapat diukur melalui kepercayaan yang dirasakan pengguna dapat ditimbulkan dari pelayanan fitur-fitur yang disediakan oleh sistem informasi yang telah disediakan. Pada penelitian ini, dimensi kepuasan pengguna mengadopsi dari penelitian DeLone dan McLean (2003) yaitu kepuasan terhadap sistem, kepuasan terhadap informasi, dan kepuasan terhadap layanan.

\section{Benefits}

Benefits merupakan manfaat yang telah diterima setelah menggunakan sistem informasi. DeLone dan McLean (2003) menyatakan benefits merupakan dampak yang dihasilkan dari aktivitas sistem informasi berupa positif maupun negatif, benefits juga merupakan suatu ukuran kinerja kesuksesan sistem informasi. Saputro et al. (2015) menyatakan benefits adalah hasil atau keuntungan yang dirasakan oleh individu dan juga organisasi setelah menerapkan sistem informasi.
DeLone dan McLean (2003) menggabungkan dua komponen model keberhasilan sistem informasi yaitu dampak individual dan dampak organisasional ke dalam komponen manfaat bersih (net benefits). Dimana manfaat dari dampak individual dilihat dari perilaku pengguna dalam menggunakan sistem informasi dalam meningkatkan kinerja. Dampak individual juga dilihat dari pemahamam pengguna yang baik, sehingga membantu pengguna dalam mengambil keputusan. Dampak organisasional dilihat dari efektivitas dari penggunaan sistem informasi yang dapat mempengaurhi biaya operasional dari suatu organisasi.

Pada penelitian ini, dimensi benefits diadopsi dari penelitian Robo et al. (2018) yaitu efektivitias, efisiensi, fasilitas informasi akademik, dan kegunaan sistem informasi.

\section{HIPOTESIS}

Menurut Arikunto (2006) hipotesis adalah suatu jawaban yang bersifat sementara terhadap permasalahan penelitian, sampai terbukti melalui data yang terkumpul. Berdasarkan permasalahan yang dikemukakan, hipotesis yang dirumuskan dalam penelitian ini adalah :

a. Kualitas sistem informasi akademik (kualitas sistem, kualitas informasi, dan kualitas layanan) terhadap kepuasan pengguna.

$\mathrm{Ho}_{(1)}$ : Kualitas sistem, kualitas informasi, dan kualitas layanan secara simultan maupun parsial tidak berpengaruh positif terhadap kepuasan pengguna sistem informasi akademik

$\mathrm{Ha}_{(1)}$ : Kualitas sistem, kualitas informasi, dan kualitas layanan secara simultan maupun parsial berpengaruh positif terhadap kepuasan pengguna sistem informasi akademik

b. Kepuasan pengguna terhadap benefits.

$\mathrm{Ho}_{(2)}$ : Kepuasan pengguna tidak berpengaruh terhadap benefits

$\mathrm{Ha}_{(2)} \quad$ : Kepuasan pengguna berpengaruh terhadap benefits 
c. Kualitas sistem informasi akademik (kualitas sistem, kualitas informasi, dan kualitas layanan) terhadap benefits.

$\mathrm{Ho}_{(3)}$ : Kualitas sistem, kualitas informasi, dan kualitas layanan secara simultan maupun parsial tidak berpengaruh positif terhadap benefits

$\mathrm{Ha}_{(3)}$ : Kualitas sistem, kualitas informasi, dan kualitas layanan secara simultan maupun parsial berpengaruh positif terhadap benefits

\section{METODE}

Objek dari penelitian ini adalah kualitas sistem, kualitas informasi, dan kualitas layanan sistem informasi akademik sebagai variabel bebas, kepuasan pengguna sebagai variabel intervening, dan benefits sebagai variabel terikat. Penelitian dilakukan di lingkungan Institut Manajemen Koperasi Indonesia.

Metode yang digunakan dalam penelitian ini adalah kuantitatif dengan pendekatan deskriptif dan verifikatif. Metode analisis data yang digunakan dalam penelitian adalah analisis jalur karena digunakan untuk mengetahui arah hubungan antar variabel bebas dengan variabel terikat melalui variabel intervening.

Sumber data yang diharapkan dapat memberikan informasi baik berupa data primer maupun data sekunder yang diperoleh dari informan (yaitu pengelola SIA di Ikopin), responden (yaitu mahasiswa sebagai pengguna SIA), dan catatan atau dokumen yang berkaitan dengan penelitian ini. Teknik pengumpulan data dilakukan dengan cara studi pustaka dan studi lapangan berupa wawancara dan observasi.

Populasi pada penelitian adalah para mahasiswa aktif sebagai pengguna SIA sebanyak 1.838 mahasiswa pada semester ganjil tahun akademik 2019/2020 yang terbagai kedalam 4 program studi yaitu D3 Manajemen Bisnis sebanyak 55 orang mahasiswa, S1 Akuntansi sebanyak 364 orang mahasiswa, S1 Ekonomi Syariah sebanyak 80 orang mahasiswa, dan S1 Manajemen sebanyak 1.339 orang mahasiswa.

Teknik pengambilan sampel menggunakan teknik proportional random sampling, dimana populasi yang heterogen dengan mengambil sampel dari tiap-tiap sub populasi secara acak dengan tujuan untuk memperoleh sampel yang representatif dengan melihat populasi mahasiswa aktif yang ada di Ikopin yang terdiri dari empat program studi.
Penentuan sampel menggunakan rumus slovin dengan rumus sebagai berikut :

$n=\frac{N}{1+N(e)^{2}}$

Keterangan :

$\mathrm{n}=$ ukuran sampel / jumlah responden

$\mathrm{N}=$ ukuran populasi

$\mathrm{e}=$ persentase kelonggaran ketelitian kesalahan pengambilan sampel yang masih bisa ditolerir ; $\mathrm{e} \leq 0,1$. Penelitian ini menggunakan $\mathrm{e}=7 \%$

$$
n=\frac{1.838}{1+1.838(0,07)^{2}}=183,686 \rightarrow 184
$$

Selanjutnya ditetapkan sampel berdasarkan program studi dengan menggunakan rumus sebagai berikut :

$n=\frac{X}{N} x N_{i}$

$\mathrm{n}=$ jumlah sampel mahasiswa aktif yang diinginkan setiap program studi

$\mathrm{N}=$ jumlah seluruh populasi mahasiswa aktif

$\mathrm{X}=$ jumlah populasi mahasiswa aktif pada setiap program studi

$\mathrm{N}_{\mathrm{i}}=$ sampel

Berdasarkan rumus tersebut, ditentukan sampel mahasiswa pada setiap program studi dengan perhitungan yang disajikan dalam tabel berikut.

Tabel 2. Ukuran Sampel tiap Program Studi

\begin{tabular}{llcccc}
\hline No. & \multicolumn{1}{c}{$\begin{array}{c}\text { Program } \\
\text { Studi }\end{array}$} & $\begin{array}{c}\text { Jumlah } \\
\text { Mahasiswa } \\
\text { Aktif } \\
{[\mathbf{A}]}\end{array}$ & $\begin{array}{c}\text { Populasi } \\
{[\mathbf{B}]}\end{array}$ & $\begin{array}{c}\text { Sampel yang } \\
\text { dibutuhkan } \\
(\mathbf{n})\end{array}$ & $\begin{array}{c}\text { Ukuran Sampel } \\
{[\mathbf{A}] /[\mathbf{B}] \mathbf{x}[\mathbf{C}]}\end{array}$ \\
\hline 1 & $\begin{array}{l}\text { D3 } \\
\text { Manajemen } \\
\text { Bisnis }\end{array}$ & 55 & 1.838 & 184 & 6 \\
2 & $\begin{array}{l}\text { S1 Akuntansi } \\
3\end{array}$ & 364 & 1.838 & 184 & 36 \\
\hline & $\begin{array}{l}\text { S1 Ekonomi } \\
\text { Syariah }\end{array}$ & 80 & 1.838 & 184 & 8 \\
\hline & $\begin{array}{l}\text { S1 } \\
\text { Manajemen }\end{array}$ & 1.339 & 1.838 & 184 & 134 \\
\hline
\end{tabular}

(Sumber : Data diolah, 2020) 


\section{HASIL DAN PEMBAHASAN}

\section{Uji Validitas dan Reliabilitas}

Uji validitas dilakukan untuk memperoleh keyakinan bahwa masing-masing pernyataan telah dikelompokkan pada variabel yang telah ditentukan. Menurut Sugiyono (2014) pengujian tiap butir digunakan analisis item, yaitu mengkorelasikan skor tiap butir dengan skor total yang merupakan jumlah tiap skor butir. Syarat minium untuk dianggap memenuhi syarat adalah kalau $r=0,30$. Apabila korelasi antara butir dengan skor total kurang dari 0,30 maka butir dalam instrumen tersebut dinyatakan tidak valid.

\section{Tabel 3. Hasil Uji Validitas}

\begin{tabular}{clcc}
\hline No. & \multicolumn{1}{c}{ Variabel } & Hasil & Simpulan \\
\hline 1 & $\begin{array}{l}\text { Kualitas Sistem } \\
\left(\mathrm{X}_{1}\right)\end{array}$ & $\mathrm{r}_{\text {hit }} \geq 0,30$ & Valid \\
2 & $\begin{array}{l}\text { Kualitas } \\
\text { Informasi }\left(\mathrm{X}_{2}\right)\end{array}$ & $\mathrm{r}_{\text {hit }} \geq 0,30$ & Valid \\
3 & $\begin{array}{l}\text { Kualitas } \\
\text { Layanan }\left(\mathrm{X}_{3}\right)\end{array}$ & $\mathrm{r}_{\text {hit }} \geq 0,30$ & Valid \\
4 & $\begin{array}{l}\text { Kepuasan } \\
\text { Pengguna }(\mathrm{Y})\end{array}$ & $\mathrm{r}_{\text {hit }} \geq 0,30$ & Valid \\
5 & Benefits $(\mathrm{Z})$ & $\mathrm{r}_{\text {hit }} \geq 0,30$ & Valid \\
\hline
\end{tabular}

(Sumber : data diolah, 2020)

Uji reliabilitas dilakukan untuk mengetahui apakah alat pengumpulan data menunjukkan tingkat ketepatan, keakuratan, kestabilan atau konsistensi alat tersebut dalam mengungkapkan gejala tertentu dari sekelompok individu walaupun dilakukan pada waktu yang berbeda. Uji reliabilitas pada penelitian ini menggunakan metode Cronbach's Alpha. Suatu instrumen dapat dikatakan reliabel jika nilai $r$ lebih dari sama dengan 0,7. Adapun hasil pengujian reliabilitas akan disajikan dalam tabel berikut.

\section{Tabel 4. Hasil Uji Reliabilitas}

\begin{tabular}{clcc}
\hline No. & \multicolumn{1}{c}{ Variabel } & Hasil & Simpulan \\
\hline 1 & $\begin{array}{l}\text { Kualitas Sistem } \\
\left(\mathrm{X}_{1}\right)\end{array}$ & $\mathrm{r}_{\text {hit }} \geq 0,70$ & Reliabel \\
2 & $\begin{array}{l}\text { Kualitas } \\
\text { Informasi }\left(\mathrm{X}_{2}\right)\end{array}$ & $\mathrm{r}_{\text {hit }} \geq 0,70$ & Reliabel \\
3 & $\begin{array}{l}\text { Kualitas } \\
\text { Layanan }\left(\mathrm{X}_{3}\right)\end{array}$ & $\mathrm{r}_{\text {hit }} \geq 0,70$ & Reliabel \\
4 & $\begin{array}{l}\text { Kepuasan } \\
\text { Pengguna }(\mathrm{Y})\end{array}$ & $\mathrm{r}_{\text {hit }} \geq 0,70$ & Reliabel \\
5 & Benefits $(\mathrm{Z})$ & $\mathrm{r}_{\text {hit }} \geq 0,70$ & Reliabel \\
\hline
\end{tabular}

(Sumber : data diolah, 2020)

\section{Uji Asumsi Klasik}

Salah satu syarat menggunakan analisis jalur selain memiliki skala data interval yaitu harus lolos uji asumsi klasik terlebih dahulu yang terdiri dari uji normalitas, uji heteroskedastisitas, dan uji multikolinearitas.

Uji normalitas bertujuan untuk menguji apakah sampel yang digunakan berdistribusi normal atau tidak. Uji normalitas menggunakan scatter plot dengan cara melihat penyebaran datanya. Adapun hasil uji normalitas akan digambarkan sebagai berikut.

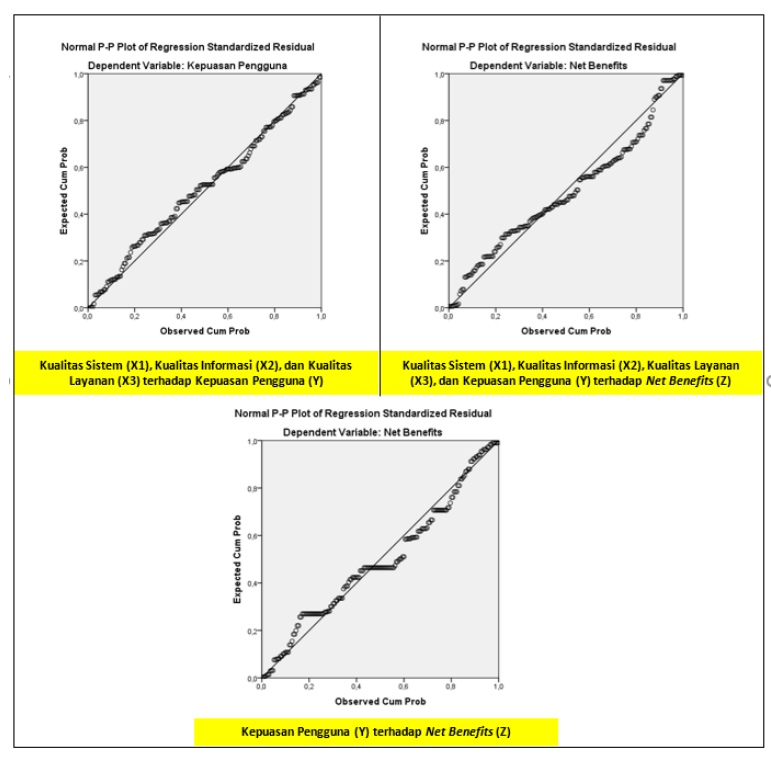

Gambar 1. Hasil Uji Normalitas Model Regresi (Sumber : Output SPSS 22.0, 2020)

Uji heteroskedastisitas bertujuan untuk menguji apakah dalam model regresi terjadi ketidaksamaan varian dari residual satu pengamatan. Uji heteroskedastisitas menggunakan uji glejser. Adapun hasil uji heteroskedastisitas akan disajikan pada tabel berikut.

\section{Tabel 5. Hasil Uji Heteroskedastisitas}

\begin{tabular}{|c|c|c|c|}
\hline No. & Variabel & Hasil & Simpulan \\
\hline 1 & $\begin{array}{l}\text { Kualitas } \\
\text { Sistem }\left(\mathrm{X}_{1}\right)\end{array}$ & $0,838 \geq 0,05$ & $\begin{array}{c}\text { Tidak terjadi } \\
\text { heteroskedastisitas }\end{array}$ \\
\hline 2 & $\begin{array}{l}\text { Kualitas } \\
\text { Informasi }\left(\mathrm{X}_{2}\right)\end{array}$ & $0,858 \geq 0,05$ & $\begin{array}{c}\text { Tidak terjadi } \\
\text { heteroskedastisitas }\end{array}$ \\
\hline 3 & $\begin{array}{l}\text { Kualitas } \\
\text { Layanan }\left(\mathrm{X}_{3}\right)\end{array}$ & $0,303 \geq 0,05$ & $\begin{array}{c}\text { Tidak terjadi } \\
\text { heteroskedastisitas }\end{array}$ \\
\hline 4 & $\begin{array}{l}\text { Kepuasan } \\
\text { Pengguna (Y) }\end{array}$ & $0,751 \geq 0,05$ & $\begin{array}{c}\text { Tidak terjadi } \\
\text { heteroskedastisitas }\end{array}$ \\
\hline
\end{tabular}

(Sumber : data diolah, 2020) 
Uji multikolinearitas bertujuan untuk menguij apakah di dalam model regresi ditemukan adanya korelasi antar variabel bebas. Adapun hasil uji multikolinearitas adalah sebagai berikut.

Tabel 6. Hasil Uji Multikolinearitas

\begin{tabular}{clcc}
\hline No. & Variabel & $\begin{array}{c}\text { Hasil } \\
\text { (Berdasarkan } \\
\text { Tolerance) }\end{array}$ & Simpulan \\
\hline 1 & $\begin{array}{l}\text { Kualitas } \\
\text { Sistem }\left(\mathrm{X}_{1}\right)\end{array}$ & $0,373 \geq 0,10$ & $\begin{array}{c}\text { Tidak terjadi } \\
\text { multikolinearitas } \\
\text { Tidak terjadi }\end{array}$ \\
2 & $\begin{array}{l}\text { Kualitas } \\
\text { Informasi }\left(\mathrm{X}_{2}\right)\end{array}$ & $0,244 \geq 0,10$ & $\begin{array}{c}\text { Tultikolinearitas } \\
\text { Tidak terjadi }\end{array}$ \\
3 & $\begin{array}{l}\text { Kualitas } \\
\text { Layanan }\left(\mathrm{X}_{3}\right)\end{array}$ & $0,308 \geq 0,10$ & $\begin{array}{c}\text { Tultikolinearitas } \\
\text { Tidak terjadi }\end{array}$ \\
4 & $\begin{array}{l}\text { Kepuasan } \\
\text { Pengguna }(\mathrm{Y})\end{array}$ & $0,258 \geq 0,10$ & $\begin{array}{c}\text { Tiltikolinearitas } \\
\text { multikn }\end{array}$
\end{tabular}

(Sumber : data diolah, 2020)

\section{Pengaruh Kualitas Sistem Informasi Akademik terhadap Kepuasan Pengguna}

Uji hipotesis pada penelitian ini dilakukan melalui uji regresi atas nilai $\mathrm{t}$ yang dirangkum pada tabel berikut.

Tabel 7. Hasil Uji Hipotesis Kualitas Sistem Informasi Akademik terhadap Kepuasan

Pengguna

\begin{tabular}{clccc}
\hline No. & $\begin{array}{l}\text { Variabel } \\
\text { Independen }\end{array}$ & $\begin{array}{c}\text { Variabel } \\
\text { Dependen }\end{array}$ & Hasil & Simpulan \\
\hline 1 & $\begin{array}{l}\text { Kualitas } \\
\text { Sistem }\left(\mathrm{X}_{1}\right)\end{array}$ & $\rightarrow \begin{array}{l}\text { Kepuasan } \\
\text { Pengguna } \\
(\mathrm{Y})\end{array}$ & $0,000<0,05$ & Signifikan \\
2 & $\begin{array}{l}\text { Kualitas } \\
\text { Informasi }\left(\mathrm{X}_{2}\right)\end{array}$ & $\begin{array}{l}\text { Kepuasan } \\
\text { Pengguna } \\
(\mathrm{Y})\end{array}$ & $0,000<0,05$ & Signifikan \\
3 & $\begin{array}{l}\text { Kualitas } \\
\text { Layanan }\left(\mathrm{X}_{3}\right)\end{array}$ & $\begin{array}{l}\text { Kepuasan } \\
\text { Pengguna } \\
(\mathrm{Y})\end{array}$ & $0,000<0,05$ & Signifikan \\
\hline
\end{tabular}

(Sumber : data diolah, 2020)

Hasil pengujian hipotesis pertama mengenai kualitas sistem informasi akademik terhadap kepuasan pengguna menunjukkan bahwa tingkat signifikansi kurang dari 0,05. Hal ini menunjukkan bahwa kualitas sistem, kualitas informasi, dan kualitas layanan memiliki pengaruh yang signifikan terhadap kepuasan pengguna.

Adapun model kualitas sistem, kualitas informasi, dan kualitas layanan secara struktural tergambar sebagai berikut.

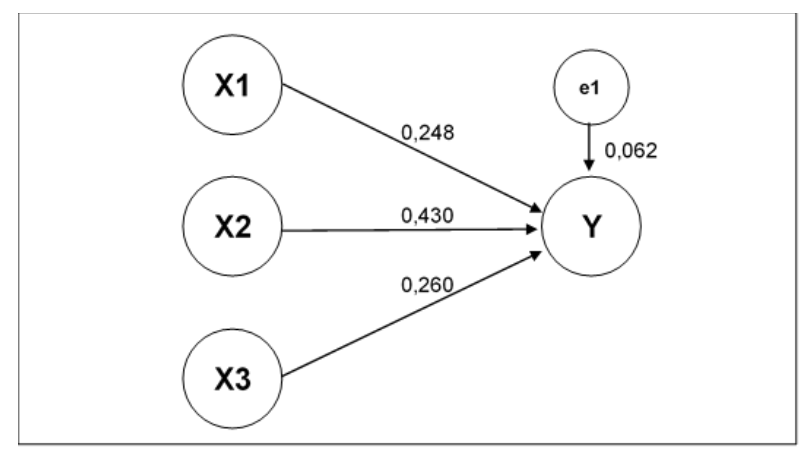

Gambar 2. Model Kualitas Sistem Informasi Akademik (Kualitas Sistem $\left(\mathbf{X}_{1}\right)$, Kualitas Informasi $\left(\mathbf{X}_{2}\right)$, dan Kualitas Layanan $\left(\mathbf{X}_{3}\right)$ ) terhadap Kepuasan Pengguna (Y)

Secara akumulatif kepuasan pengguna dipengaruhi oleh kualitas sistem informasi akademik sebesar $0,938(93,8 \%)$ dan sisanya $0,062(6,2 \%)$ dipengaruhi oleh faktor-faktor lain yang tidak diteliti pada penelitian ini seperti intensitas penggunaan, pengalaman pengguna (user experience), interaksi pengguna (user interface), dan perilaku pengguna.

Dewasa ini user experience dan user interface atau biasa disingkat dengan UI/UX merupakan salah satu menentukan peningkatan kepuasan pengguna dalam mengakses suatu website. Guo (dalam Munthe et al., 2018) menyebutkan UX dapat membuat situs web lebih mudah digunakan, berharga, dan efektif bagi pengunjung. Fokusnya adalah pada kesenangan dan nilai daripada kinerja. Kemudahan dalam mengakses suatu website merupakan nilai tambah bagi pengunjung, sehingga ketika pengunjung merasa nyaman dalam mengakses suatu website maka akan terjadi peningkatan kepuasan pengguna (Munthe et al., 2018).

\section{Pengaruh Kepuasan Pengguna terhadap Benefits}

Uji hipotesis pada penelitian ini dilakukan melalui uji regresi atas nilai t yang disajikan pada tabel berikut.

Tabel 8. Hasil Uji Hipotesis Kepuasan Pengguna terhadap Benefits

\begin{tabular}{clclcc}
\hline No. & $\begin{array}{c}\text { Variabel } \\
\text { Independen }\end{array}$ & $\begin{array}{c}\text { Variabel } \\
\text { Dependen }\end{array}$ & Hasil & Simpulan \\
\hline 1 & $\begin{array}{l}\text { Kepuasan } \\
\text { Pengguna }(Y)\end{array}$ & $\rightarrow \begin{array}{l}\text { Benefits } \\
(Z)\end{array}$ & $0,000<0,05$ & Signifikan \\
\hline
\end{tabular}

(Sumber : data diolah, 2020) 
Hasil pengujian hipotesis kedua mengenai kepuasan pengguna terhadap benefits menunjukkan bahwa tingkat signifikansi yaitu sebesar 0,000 kurang dari 0,05 . Hal ini menunjukkan bahwa kepuasan pengguna memiliki pengaruh yang signifikan terhadap benefits.

Adapun model kepuasan pengguna terhadai benefits dapat digambar secara struktural sebagai berikut.

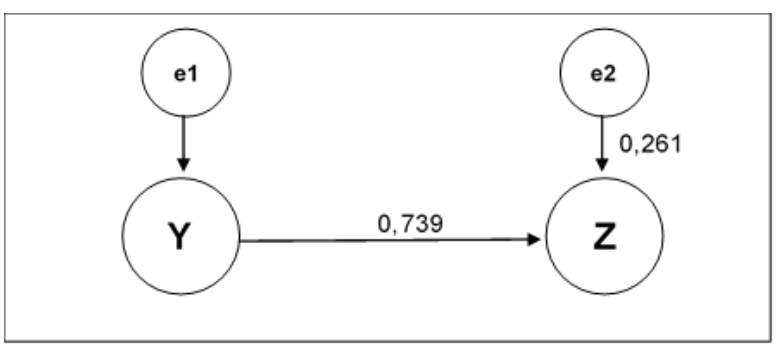

Gambar 3. Model Kepuasan Pengguna (Y) terhadap Benefits $(\mathbf{Z})$

Benefits dipengaruhi oleh kepuasan pengguna sebesar $0,739(73,9 \%)$ dan sisanya $0,261(26,1 \%)$ dipengaruhi oleh faktor-faktor lain yang diantaranya bisa berupa karakteristik pengguna, dukungan dari top management, dan faktor-faktor lain yang tidak diteliti pada penelitian ini. Hasil penelitian ini sejalan dengan hasil penelitian yang dilakukan oleh Jumardi et al. (2015), Fathoni et al. (2017), dan Robo et al. (2018) yang menunjukkan bahwa kepuasan pengguna berpengaruh signifikan terhadap benefits sistem informasi akademik.

\section{Pengaruh Kualitas Sistem Informasi Akademik terhadap Benefits melalui Kepuasan Pengguna}

Uji hipotesis pada penelitian ini dilakukan melalui uji regresi atas nilai t yang dirangkum pada tabel berikut.

Tabel 9. Hasil Uji Hipotesis Kualitas Sistem Informasi Akademik terhadap Benefits

\begin{tabular}{|c|c|c|c|c|}
\hline No. & $\begin{array}{c}\text { Variabel } \\
\text { Independen }\end{array}$ & $\begin{array}{c}\text { Variabel } \\
\text { Dependen }\end{array}$ & Hasil & Simpulan \\
\hline 1 & $\begin{array}{l}\text { Kualitas } \\
\text { Sistem }\left(\mathrm{X}_{1}\right)\end{array}$ & $\begin{aligned} & \rightarrow \text { Benefits } \\
&(Z)\end{aligned}$ & $0,000<0,05$ & Signifikan \\
\hline 2 & $\begin{array}{l}\text { Kualitas } \\
\text { Informasi }\left(\mathrm{X}_{2}\right)\end{array}$ & $\begin{array}{l}\Rightarrow \text { Benefits } \\
(Z)\end{array}$ & $0,003<0,05$ & Signifikan \\
\hline 3 & $\begin{array}{l}\text { Kualitas } \\
\text { Layanan }\left(\mathrm{X}_{3}\right)\end{array}$ & $\begin{array}{l}\rightarrow \begin{array}{l}\text { Benefits } \\
(Z)\end{array}\end{array}$ & $0,011<0,05$ & Signifikan \\
\hline
\end{tabular}

(Sumber : data diolah, 2020)

Hasil pengujian hipotesis ketiga mengenai kualitas sistem informasi akademik terhadap benefits menunjukkan bahwa tingkat signifikan kurang dari 0,05. Hal ini menunjukkan bahwa kualitas sistem, kualitas informasi, dan kualitas layanan memiliki pengaruh yang signifikan terhadap benefits.
Adapun model kualitas sistem informasi akademik terhadap benefits melalui kepuasan pengguna tergambar sebagai berikut.

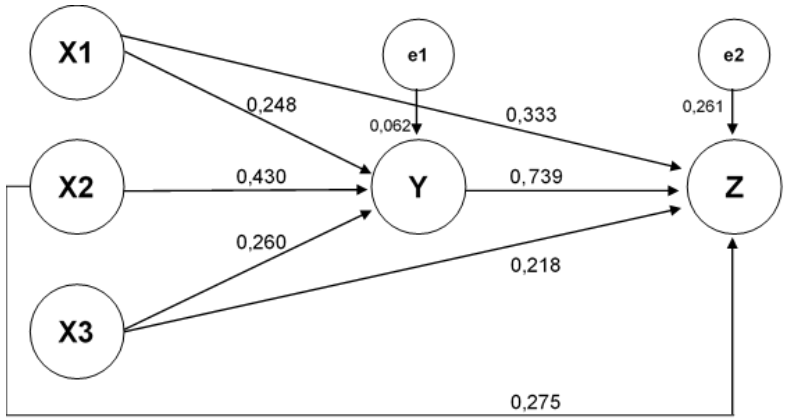

Gambar 4. Model Kualitas Sistem Informasi Akademik terhadap Benefits melalui Kepuasan Pengguna

Rincian mengenai pengaruh langsung dan tidak langsung dari kualitas sistem informasi akademik terhadap benefits melalui kepuasan pengguna adalah sebagai berikut.

Tabel 10. Rincian Hitungan Koefisien Jalur

\begin{tabular}{|c|c|c|c|c|c|}
\hline \multirow[b]{2}{*}{ No. } & \multirow{2}{*}{$\begin{array}{c}\text { Variabel } \\
\text { Independen }\end{array}$} & \multirow{2}{*}{$\begin{array}{c}\text { Variabel } \\
\text { Dependen }\end{array}$} & \multicolumn{3}{|c|}{ Pengaruh } \\
\hline & & & Langsung & $\begin{array}{c}\text { Tidak } \\
\text { Langsung }\end{array}$ & Total \\
\hline 1 & $\begin{array}{l}\text { Kualitas } \\
\text { Sistem }\left(\mathrm{X}_{1}\right)\end{array}$ & $\begin{aligned} \rightarrow & \text { Benefits } \\
& (Z)\end{aligned}$ & 0,333 & 0,246 & 0,579 \\
\hline 2 & $\begin{array}{l}\text { Kualitas } \\
\text { Informasi }\left(\mathrm{X}_{2}\right)\end{array}$ & $\begin{aligned} \rightarrow & \text { Benefits } \\
& (Z)\end{aligned}$ & 0,275 & 0,203 & 0,478 \\
\hline 3 & $\begin{array}{l}\text { Kualitas } \\
\text { Layanan }\left(\mathrm{X}_{3}\right)\end{array}$ & $\begin{array}{l}\rightarrow \quad \begin{array}{l}\text { Benefits } \\
(Z)\end{array} \\
\end{array}$ & 0,218 & 0,161 & 0,379 \\
\hline
\end{tabular}

(Sumber : data diolah, 2020)

Upaya Manajemen untuk Meningkatkan Benefits Sistem Informasi Akademik

Upaya-upaya yang diusulkan untuk manajemen dibagi menjadi tiga tingkatan yaitu upaya untuk topmanagement yaitu Direktur Program Studi, middlemanagement yaitu Direktur Akademk, dan lowmanagement yaitu Kepala Bagian IT.

Bagi top-management yaitu Direktur Program Studi perlu mempertimbangkan perencanaan integrasi sistem informasi akademik dengan sistem informasi manajemen yang lainnya seperti sistem informasi keuangan untuk meningkatkan efisien layanan kepada mahasiswa Ikopin. Selain itu juga, sistem e-learning atau learning management system (LMS) berupa kuliah daring saat ini sangat populer pada institusi pendidikan, alangkah baiknya hal tersebut juga direncanakan dalam jangka waktu menengah agar Ikopin memiliki nilai tersendiri bagi para 
mahasiswanya sehingga tidak memerlukan aplikasi pihak ketiga saat melaksanakan kuliah daring.

Bagi middle-management yaitu Direktur Akademik dapat merencanakan peningkatan sistem yang telah ada berupa kenyamanan saat mengakses SIA, peningkatan keamanan data dan informasi mahasiswa, serta waktu respon SIA guna memperbaiki kualitas SIA di Ikopin yang berdampak pada kepuasan pengguna mahasiswa Ikopin.

Bagi low-management yaitu Kepala Bagian IT dapat meningkatkan motivasi dan keterampilan operator dalam mengoperasikan SAKTI serta pelatihan secara berkala untuk meningkatkan kualitas layanan kepada para mahasiswa.

\section{SIMPULAN DAN SARAN}

\section{Simpulan}

Berdasarkan hasil penelitian yang telah diuraikan sebelumnya, kualitas sistem informasi akademik yang terdiri dari kualitas sistem, kualitas informasi, dan kualitas layanan terbukti memberikan pengaruh yang signifikan terhadap benefits melalui kepuasan pengguna. Hal ini menunjukkan bahwa semakin baik kualitas sistem informasi akademik yang tersedia dapat meningkatkan kepuasan penggua dan mampu meningkatkan manfaat yang diberikan oleh sistem informasi akademik kepada mahasiswa sebagai pengguna.

\section{Saran}

Saran-saran yang dapat diberikan yaitu pengelola diharapkan mampu meningkatkan kualitas sistem, kualitas informasi, kualitas layanan, kepuasan pengguna dalam upaya untuk meningkatkan manfaat yang dirasakan oleh pengguna sistem informasi akademik di Ikopin.

\section{DAFTAR PUSTAKA}

Arikunto, S. 2006. Prosedur Penelitian Suatu Pendekatan Praktik. Jakarta : Rineka Cipta.

DeLone, W. H. \& McLean E. R. (1992). Information Systems Success: The Quest for the Dependent Variable. Information Systems Research, 3(1), 6085, https://doi.org/10.1287/isre.3.1.60.

. (2003). The DeLone and McLean Model of Information Systems Success: A Ten-Year Update. Journal of Management Information Systems, 19(4), 9-30. https://doi.org/10.1080/07421222.2003.11045748.

Fathoni, M. A., Indah G., \& Suharso, W. (2017). Analisis Pengaruh System Quality, Information Quality, Service Quality terhadap Net Benefit pada Sistem KRS-Online Universitas Muhammadiyah Malang. KINETIK Game Technology, Information System, Computer Network, Computing, Electronics and Control, 2(3), 197-206, https://doi.org/10.22219/kinetik.v2i3.65.

Jumardi, R., Nugroho, E. \& Hidayah, I. (2005). Analisis Kesuksesan Implementasi Sistem Informasi Skripsi pada Program Studi Teknik Informatika Universitas Pembangunan Nasional “Veteran” Yogyakarta. Seminar Nasional Aplikasi Teknologi Informasi (SNATi) 2016 Yogyakarta.

Kerta, J. M. \& Suryawan, A. D. (2013). Analysis of Information System Implementation in Binus University Using Delone and Mclean Information System Success Model and Cobit Framework. Communication and Information Technology Journal, $\quad 7(1), \quad$ 13-17, https://doi.org/10.21512/commit.v7il.578.

Livari, J. (2005). An Empirical Test of the DeLoneMcLean Model of Information System Success. The DATA BASE for Advances in Information Systems, $\quad 36(2), \quad 8-27$, https://doi.org/10.1145/1066149.1066152.

Munthe, R. D., Brata, K. C., \& Fanani, L. (2017). Analisis User Experience Aplikasi Mobile Facebook (Studi Kasus pada Mahasiswa Universitas Brawijaya). Jurnal Pengembangan Teknologi Informasi dan Ilmu Komputer, 2(7), 2679-2688. Diambil dari https://jptiik.ub.ac.id/index.php/j-ptiik/article/view/1672

Ojo, A. I. (2017). Validation of the DeLone and McLean Systems Success Model. Health Informatics Research, 23(1), 60-66, https://doi.org/10.4258/hir.2017.23.1.60.

Robo, S., Setyohadi, D. B. \& Santoso, A. J. (2018). An Identification of Success of Academic System Application Using Delone and Mclean Design. International Conference on Information and Communications Technology (ICOIACT) 2018.

Saputro, P. H., Budiyanto, A. D., \& Santoso, A. J. (2015). Model Delone dan Mclean untuk Mengukur Kesuksesan E-government Kota Pekalongan. Scientific Journal of Informatics, 2(1), 1-8, https://doi.org/10.15294/sji.v2il/4523.

Sudarmadi. (2010). Faktor-Faktor yang Mempengaruhi Kepuasan Pengguna Sistem Informasi (Studi pada Aparat Pemerintah Daerah Kabupaten Sragen). Jurnal Akuntansi dan Bisnis, 10(2), https://doi.org/10.20961/jab.b10i2.115. 
322 Coopetition, Vol XII, Nomor 3, Juli 2021

(E-ISSN : 2615-4978, P-ISSN : 2086-4620)

Sugiyono. 2014. Metode Penelitian Manajemen. Bandung : Alfabeta.

Utami, A. W. \& Samopa, F. (2013). Analisa Kesuksesan Sistem Informasi Akademik (SIAKAD) di Perguruan Tinggi dengan Menggunakan D \& M IS Success Model (Studi Kasus: ITS Surabaya). Jurnal Sistem Informasi, 4(5), 294-309, https://doi.org/10.24089/j.sisfo.2013.09.001. 